\title{
全球の統計的波高推定手法の開発と 将来変化予測への応用
}

\author{
森 信人 1 ・岸本理紗子 $2 \cdot$ 志村智也 $3 \cdot$ 安田誠宏 4 ・間瀬 $\quad$ 肇 5 \\ 1正会員 京都大学准教授 防災研究所（７611-0011京都府宇治市五尔庄） \\ E-mail:mori@oceanwave.jp \\ 2学生会員 京都大学大学院 工学研究科（二 $615-8530$ 京都府京都市西京区京都大学桂） \\ E-mail:kisimoto.risako.65z@st.kyoto-u.ac.jp \\ 3正会員 京都大学特別研究員 防災研究所（二611-0011京都府宇治市五厅庄） \\ 4正会員 京都大学助教 防災研究所（干611-0011京都府宇治市五厅庄） \\ 5正会員 京都大学教授 防災研究所（干611-0011京都府宇治市五尔庄）
}

\begin{abstract}
JRA-55を基本データとし, 力学的波浪モデルと比べて短時間で数多くの気候変動に関するアンサンブル 予測に適用できる波高の統計的予測モデルを開発した。得られた予測モデルを幾つかの温室効果ガスの将 来濃度シナリオにもとづいた気候変動予測結果に適用し, 平均波高および極大波高の将来変化予測を行っ た. 主な将来変化としては, 平均波高に対して北太平洋北部で波高の増加, 北大西洋全域と北緯 - 南緯 30 付近, および太平洋赤道域の東部で大きな減少が見られ, 極大波高は, 概ね平均波高と同様の変化の 分布を示した．極大波高が平均波高と異なる特徵を示した海域は，主に熱帯低気圧が通過する頻度が高い 海域であり, その将来変化傾向は, 温室効果ガスの将来濃度シナリオによって多様な傾向を示した。
\end{abstract}

Key Words : climate change, wave climate, wave projection, statistical model, emission scenario

\section{1. はじめに}

温室効果ガスによる気候変動が人間生活に与える影響 が徐々に懸念されており，我が国においても様々なセク ターに対する影響評価と適応策の検討が行われつつある。 気候変動の影響は浻岸環境にも大きくおよび，想定され る沿岸域への気候変動の直接的な影響としては，海面上 昇，高潮および波浪の変化があるが，波浪は他の要素と 比較して予測評価研究が進んでおらず，現在の気候モデ ルでは直接予測されていない。しかし，大気循環場等の 広域の気候変化は，波浪に影響を与えることが予想され る1). 海面上昇，高潮および波浪といった沿岸外力の将 来変化は, 沿岸域における海浜変形, 構造物の設計条件, 生態系等，広い分野と深く関連するため，定量的な将来 予測が必要とされている21.

上記のように，沿岸外力の長期的な将来変化予測は重 大な課題であり，波浪については気候モデルの計算結果 を踏まえてその将来変化を予測する必要がある. 全球を 対象とする波高の将来変化予測については，2010年以降， 平均波高について幾つかの予測が行われているが，アン サンブル数が少なく，不確実性の評価まで至っていない.
また，極大波高については，取り扱いの難しさから確度 の高い将来予測はほとんど行われていない.さらに IPCC第5次評価報告書（IPCC AR5）以降，気候モデルに よる将来変化の予測数が飛躍的に増え，予測の不確実性 評価が可能となりつつあるものの，一方で影響評価の計 算負荷も大幅に増えている.

一般に，波浪の予測・推算には，力学的手法が用いら れる3). 力学的手法を用いた波浪の将来変化予測では, 気候モデルから予測された海上風と海水のデータを外 力・境界条件に，スペクトル型波浪モデルを用いて長期 積分が行われる4). 支配方程式に従って計算を行うため, 得られたスペクトル情報にもとづき, 波高, 周期, 波向 き等の波浪についての様々な情報を出力できるが，計算 負荷が高く, 数十年に渡る将来変化を予測するには，時 間がかかることが欠点である，一方で，波浪の将来変化 を統計的手法によって予測する研究も試みられている5, 統計的手法では, 過去の気象变数と波浪変数の統計的関 係を事前に求め, 気候モデルから出力された気象データ をその関係に適用して波浪場の推定を行う．将来の波浪 を計算する際は，その関係が将来においても保持される という仮定の下で，将来の気象データを使って波浪場の 
推定を行う. 統計的手法では，計算時間を大幅に短縮す ることが可能であり，多くの気候変動予測結果に適用す ることできる. しかし，統計的手法では，気象変数と波 浪変数の統計的関係にもとづくため, その精度やベンチ マークとなる過去データの推算精度に波浪の推定精度が 依存する．特に，風浪についてのフェッチやうねりの影 響予測の精度が問題となる。

これらの現状から，波浪の将来変化を求めるための統 計モデルを作成し，多くの気候の将来変化予測シナリオ を対象に，波浪の予測計算を統計的に行い，不確実性の 評価を行うことが必要とされている。したがって, 本研 究では，まず短時間で多くのアンサンブルに適用可能な 波浪の統計モデルを開発する．ついで，第5期結合モデ ル相互比較計画（CMIP5）における幾つかの温室効果ガ スの将来濃度シナリオ条件下の気候変動予測結果に適用 し，月平均波高および極大波高の将来変化予測を行う.

\section{2. 波浪の統計的予測手法の開発と精度検証}

\section{(1) 計算方法}

波浪の統計的な将来変化予測を行うため，予測手法の 開発を行った. 統計モデル構築のために用いた基本デー 夕は, JRA-55長期再解析值 ${ }^{7}$ の海上 $10 \mathrm{~m}$ 高度風速 $\left(U_{10}\right)$, 海面更正気圧 $(S L P)$, およびJA-55で出力された風と 海水のデータを外力に, 波浪スペクトルモデルWAVE WATCHIII v4.18)を用いて計算された波浪解析値9)(以下 JRA-55+Wave再解析と表記）の波高（ $H_{S} ）$ である. 波 高データは緯度経度格子 $0.5625^{\circ} \times 0.5625^{\circ}$ の解像度で, 1 時間毎の出力を用いた. 風速と海面更正気圧データの空 間解像度はそれぞれ約 $60 \mathrm{~km}$ と $1.25^{\circ} \times 1.25^{\circ}$ であり，6時間 毎 $(0,6,12$, 18UTC) の出力を用いた.さらにSLPの勾配 は, 中心差分で求めた.

統計モデルの構築は，まず，JRA-55+Wave 再解析か ら解析期間前半の1958 1987 年（30年間）の6時間毎の 波高，月平均波高，年99\%值および99.9\%值等（極大波 高と定義) のデータを格子点毎に取り出す.また, 海上 風速, 海面気圧のデータも同様に取り出す. 海上風速の 2乗 $\left(U_{10}^{2}\right.$, 以下 $U_{10}^{2}$ と略記 $)$, 海面気圧 $(S L P)$, 海面 気圧の勾配 $(\triangle S L P$, 以下 $\triangle S L P$ と略記) のうち1つから 3 つを組み合わせて説明変数とした. 波高と説明変数の間 に以下の線形関係を考え, 格子点毎に波高の予測值 $\left(\widehat{H}_{S}\right)$ と再解析值 $\left(H_{S}\right)$ の差の 2 乗和が最小になるよう に定数 $(a)$ および係数 $\left(b_{i}\right)$ を決定した.

$$
\hat{H}_{S}=a+\sum_{i=1}^{k} b_{i} x_{i}
$$

ここで, $k$ は説明変数の数, $x_{i}$ は説明変数を表している. 得られた統計モデルを用いて, 再解析の解析期間後半 （1988～2012年）の説明変数の值から6時間毎の波高,
月平均波高，極大波高を予測し，精度検証を行った．大 気再解析データの説明変数 $U_{10}^{2}, S L P$ および $\Delta S L P$ の組 み合わせを変えて，合計7パターンの結果を比較検討し， 格子点毎の線形回帰モデルの最適な予測手法を選択した.

\section{(2) 検証結果}

JRA-55+Wave再解析の前半30年間のデータから得ら れた統計モデルを用いて, 後半 25 年間の解析值を対象に 精度の検証を行った，以下では，推定精度の特性につい ての考察を行う.

\section{a) 月平均波高の推定特性}

推定された月平均波高とJRA-55+Wave再解析の解析 值との相関係数を, 図-1に示した9つの海域毎に平均し た結果を表-1に示寸. 全球平均の相関については, 0.8 以上の高い相関が得られ，3つの説明変数を全て用いた モデルが最も相関が良かった。一方，SLPのみを説明変 数としたモデルは，ほぼ無相関となった。

海域毎に見ると，すべてのモデルで北インド洋の相関 が最も高くなることがわかる，一方，赤道域はどのモデ ルを用いても相関は最も低くなっており，それに次いで 北太平洋も低くなっている. 後で詳細に解析寸るが, こ れらの海域ではうねりが卓越しており，このため格子点 毎に定義した統計的関係では精度が低下している. 全て の海域で, 最も相関係数が大きいのは説明変数を $3 つ$ 全 てとしたモデルであった．南極海では比較的誤差が大き いが, これは海水の季節変動が激しく, 季節によりフェ ッチが変化するためと考えられる. 物理モデルでは海水 の変動の情報も考慮して計算を行っているため, 海水の 季節変動を考慮しない統計モデルでは再現が難しく, 大 きな差が生じることがわかった。

紙面の制約上図示しないが，平均波高推定誤差の空間 分布より, 推定誤差は, 赤道域や北緯 $20^{\circ}$ 近辺, 南緯 $30^{\circ}$ 近辺の中緯度において, 大陸の西側で誤差の大きな海域 が带状に現れることがわかった．本研究では，格子点毎 の波高と風の関係に注目してモデリングを行っているた め, 偏西風や貿易風の吹く海域では, 年間を通じて風が 強く，風波が支配的であり，このため相関が良いと考え られる. 逆に，赤道域のように風が強くなく，う衫りが 卓越する海域では相関が低い。しかし，赤道域では平均 波高が小さいために, 絶対的な誤差は小さい. また，風 が強い海域でも，その場で生成される風波よりもうねり の影響が卓越する南北アメリカ大陸等の大陸の西側では 相関が低くなる．北大西洋では，平均波高が大きいため, 相関係数が大きいにも関わらず誤差は大きい.

\section{b) 極大波高の推定特性}

表-2に示寸ように，極大波高の推定では，風波が飽和 し，吹送距離が無限であるという仮定（局所平衡）が厳 しいため, 波高のばらつきが大きくなり，相関が悪くな 
った．説明変数の組み合わせについては， $U_{10}^{2}$ のみを説 明変数とするモデルで最も相関が良かった. 平均波高と 同様に，極大波高についても風の強い海域では相関が良 く, 赤道域のような風の弱い海域では相関が悪くなった。 風の強い海域でも，風の強さよりうねりの影響が卓越す る，南北アメリカ大陸やオーストラリア大陸，アフリカ 大陸の西側では相関が悪い. 誤差の空間分布によれば, 日本の南側や北太平洋中央, 北大西洋の北東部, 南極海 で比較的大きな誤差を示す．このうち，日本の南側や北 太平洋中央, 北大西洋の北東部では，極大波高が他の海 域と比較して高いため，相関が良いにも関わらず誤差は 大きくなる．南極海については，極大波高はそれほど大 きくなく誤差も非常に大きいため, どのモデルでも波高 予測の信頼性は比較的低い.

説明変数を変えたモデル毎の特徵に注目すると，月平 均波高の場合と異なり， $U_{10}^{2}$ のみ説明変数とするモデ ルが最も相関が良く，誤差も少ない. SLPに関する説明 変数のみのモデルでは, 特に北インド洋や赤道域での相 関が悪い，これは，極大波の生成条件では，局所平衡が 成り立つ風波が支配的なためである. $U_{10}^{2}$ が説明変数に 加わると全体的に相関が良くなるが，南太平洋ではあま り改善が見られない. $U_{10}^{2}$ と $S L P, U_{10}^{2}$ と $\Delta S L P$ のつのモ デルでは，結果にほとんど差はなく，わずかに後者のほ うが相関が良い，これは，風に直接的に影響を与えるの がSLPではなく勾配であるからだと考えられる。

\section{c) 回帰係数の分布}

説明変数が波高の予測に与える影響を調べるために, 平均波高推定における線形回帰式の係数について検証を 行った. $U_{10}^{2}$ のみを説明変数にした場合の係数の分布を 図-1に示寸．広い海域で $0.02 \sim 0.03\left[\mathrm{~s}^{2} / \mathrm{m}\right]$ の值となること がわかる．これは，以下に示すフェッチが無限の場合の JONSWAPの条件0.0203に近い值である.

$$
H_{S}=\frac{0.0094\left(\frac{\omega_{p}}{2 \pi g} U_{10}\right)^{-5 / 3}}{g} U_{10}^{2} \cong 0.0203 U_{10}^{2}
$$

係数がこの範囲の值をとる海域では誤差が小さい，一方， 北太平洋北部，北大西洋およびインドの西側等では，西 部から東部に向けて係数が増加し，0.03を超える．この 変化に伴って, 誤差も微増している. これはこの海域で 偏西風が東向きに吹き，風下となる東部ではフェッチが 大きくなるためと考えられる. 南半球の南部では, 同様 に偏西風が吹くが，北半球と比較すると，大陸に風が遮 られることが少ないため係数の変動があまり生じず, 誤 差が小さい. また, 係数が著しく小さい赤道付近, オー ストラリア大陸西側, 南アメリカ大陸西側, アフリカ大 陸西側の海域では, 波高が小さいため, 誤差が大きい.

\section{d) 月毎の相関係数の分布}

上記の結果を踏まえ, 最も相関の良かった，3つの説 明変数全てを用いたモデルについて，詳細な傾向を調べ

表-1 推定された月平均波高とJRA-55との相関係数（太字は最も相関係数が高いモデル）

\begin{tabular}{c|c|c|c|c|c|c|c}
\hline \multirow{2}{*}{ 海域 } & \multicolumn{7}{|c}{ 統計モデルの説明変数 } \\
\cline { 2 - 8 } & $U_{10}^{2}$ & $S L P$ & $\Delta S L P$ & $U_{10}^{2}, S L P$ & $U_{10}^{2}, \Delta S L P$ & $S L P, \Delta S L P$ & $U_{10}^{2}, S L P, \Delta S L P$ \\
\hline 北インド洋 & 0.91 & 0.68 & 0.83 & 0.96 & 0.93 & 0.90 & $\mathbf{0 . 9 6}$ \\
北西太平洋 & 0.90 & 0.36 & 0.81 & 0.91 & 0.91 & 0.84 & $\mathbf{0 . 9 2}$ \\
北東太平洋 & 0.79 & 0.49 & 0.71 & 0.81 & 0.83 & 0.76 & $\mathbf{0 . 8 4}$ \\
北大西洋 & 0.87 & 0.39 & 0.80 & 0.88 & 0.89 & 0.81 & $\mathbf{0 . 8 9}$ \\
南インド洋 & 0.81 & 0.43 & 0.73 & 0.87 & 0.85 & 0.81 & $\mathbf{0 . 8 8}$ \\
南太平洋 & 0.82 & 0.36 & 0.76 & 0.83 & 0.83 & 0.77 & $\mathbf{0 . 8 4}$ \\
南大西洋 & 0.84 & 0.41 & 0.76 & 0.87 & 0.85 & 0.81 & $\mathbf{0 . 8 8}$ \\
赤道域 & 0.67 & 0.32 & 0.56 & 0.72 & 0.70 & 0.63 & $\mathbf{0 . 7 5}$ \\
南極海 & 0.83 & 0.30 & 0.78 & 0.84 & 0.83 & 0.80 & $\mathbf{0 . 8 5}$ \\
\hline 全球 & 0.81 & 0.39 & 0.73 & 0.84 & 0.83 & 0.77 & $\mathbf{0 . 8 5}$ \\
\hline
\end{tabular}

表-2 推定された99\%極大波高のとJRA-55との相関係数（太字は最も相関係数が高いモデル）

\begin{tabular}{c|c|c|c|c|c|c|c}
\hline \multirow{2}{*}{ 海域 } & \multicolumn{7}{|c}{ 統計モデルの説明変数 } \\
\cline { 2 - 8 } & $U_{10}^{2}$ & $S L P$ & $\Delta S L P$ & $U_{10}^{2}, S L P$ & $U_{10}^{2}, \Delta S L P$ & $S L P, \Delta S L P$ & $U_{10}^{2}, S L P, \Delta S L P$ \\
\hline 北インド洋 & $\mathbf{0 . 7 8}$ & 0.07 & 0.33 & 0.76 & 0.77 & 0.32 & 0.76 \\
北西太平洋 & 0.77 & 0.01 & 0.62 & 0.76 & $\mathbf{0 . 7 7}$ & 0.59 & 0.76 \\
北東太平洋 & $\mathbf{0 . 6 6}$ & 0.07 & 0.53 & 0.65 & 0.66 & 0.49 & 0.64 \\
北大西洋 & $\mathbf{0 . 7 4}$ & 0.04 & 0.52 & 0.70 & 0.72 & 0.48 & 0.69 \\
南インド洋 & $\mathbf{0 . 6 5}$ & 0.07 & 0.51 & 0.64 & 0.65 & 0.49 & 0.64 \\
南太平洋 & $\mathbf{0 . 6 2}$ & 0.08 & 0.54 & 0.61 & 0.62 & 0.53 & 0.61 \\
南大西洋 & $\mathbf{0 . 6 1}$ & -0.02 & 0.50 & 0.59 & 0.59 & 0.48 & 0.58 \\
赤道域 & $\mathbf{0 . 4 6}$ & 0.04 & 0.27 & 0.44 & 0.45 & 0.26 & 0.44 \\
南極海 & 0.46 & 0.08 & 0.42 & 0.44 & $\mathbf{0 . 4 8}$ & 0.41 & 0.46 \\
\hline 全球 & $\mathbf{0 . 6 0}$ & 0.05 & 0.47 & 0.58 & 0.60 & 0.45 & 0.58 \\
\hline
\end{tabular}




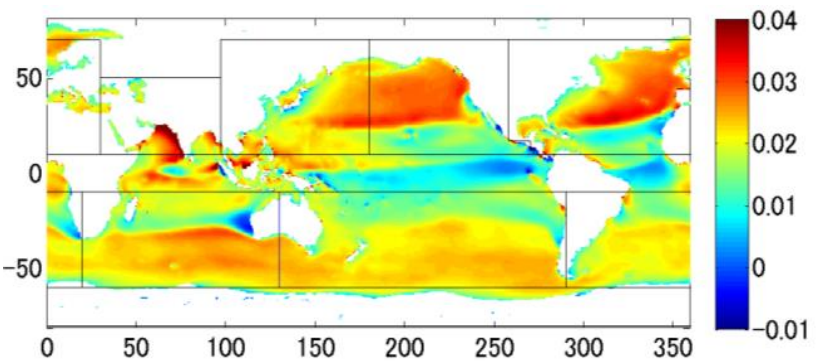

図-1 平均波高の推定式における $U_{10}^{2}$ の係数の分布 $\left[\mathrm{s}^{2} / \mathrm{m}\right]$ (説明変数: $U_{10}^{2}$ のみの場合)

るため，月毎に算出した海域別の相関係数を表-3に示す まず，太平洋では2月や3月，南大西洋では1月から3月に かけて, 北大西洋では2月と12月，北インド洋では3月と 4月に相関係数が小さくなっている. 誤差の空間分布を 見ると，特に大陸の西側で相関係数は小さくなっている オーストラリア大陸の西側では1月から3月，赤道域では 7月から9月，南極海では9月から10月にかけて相関係数 が高くなる.一般的に，夏より冬のほうが風が強いため， 風の影響が卓越し，南太平洋や南大西洋，南極海では冬 季に相関が良くなり，夏季に相関が低くなる.

紙面の制約上示していないが， $U_{10}^{2}$ のみを説明変数に したモデルにおいても同様の季節変動の傾向が見られた。 説明変数が3つのモデルでは， $U_{10}^{2}$ のみを説明変数にし たモデルより全体的に相関が良くなり，誤差も減少した。 また， $U_{10}^{2}$ の夕のモデルで顕著であった，2月の北東太 平洋や，9月，11月の南アフリカの西での極端な負の相 関は，説明変数を3つにすることで軽減された.

\section{3. 将来変化の予測計算}

\section{(1) 気候変動予測モデルの概要}

上記で得られた統計モデルを全球気候変動予測の結果 に適用し, 波高の将来変化予測に適用した. 波高変化予 測に用いる統計モデルは，前章で精度検証を行った結果 を踏まえ， $U_{10}^{2}$ のみを説明変数とするモデル， $U_{10}^{2}$ と $\triangle S L P$ を用いたモデル， $U_{10}^{2}, S L P, \Delta S L P$ のつの説明変 数を全て用いたモデルの3つとした. 将来気候の予測結 果は, 気象庁気象研究所高解像度全球大気モデル
（MRI-AGCM3.2H）による気候変動予測実験の結果10)を 用いた，空間解像度は約 $60 \mathrm{~km}$ （TL319）である. この予 測では，現在気候を1979～2004年，将来気候を2075〜 2100年（共に26年間）としてタイムスライス実験を行っ ている. MRI-AGCM3.2Hは海面水温（Sea Surface Temperature, 以下SSTと略記）を外力とし，大気の時間積分を行 う Atmosphere Global Climate Model（AGCM）である．将来 の温暖化シナリオは，IPCC第5次評価報告書（AR5）で 用いられている，大気中の温室効果ガスによる放射強制 力の変化を示す代表的濃度経路 (RCP) シナリオ中の, RCP2.6, RCP4.5, RCP6.0, RCP8.5の4通りである. RCPシ ナリオ毎にAR5で用いられたCMIP5モデルのアンサンブ ル平均SSTを与えて予測実験が行われている.これに加 えて現在気候のデータも用いて波浪の解析を行った。

統計モデルは緯度経度格子 $0.5625^{\circ} \times 0.5625^{\circ}$ の解像度で あるのに対し, MRI-AGCM3.2Hの解像度は約 $60 \mathrm{~km}$ である. したがって MRI-AGCM3.2Hのデータを緯度経度格子 $0.5625^{\circ} \times 0.5625^{\circ}$ に線形内扱し，解析を行った. ただし， MRI-AGCM3.2Hの気圧勾配の算出の際は，統計モデルの 気圧勾配と同じく, 緯度経度格子 $1.25^{\circ} \times 1.25^{\circ}$ で算出し, その值を緯度経度格子 $0.5625^{\circ} \times 0.5625^{\circ}$ に線形内挿した。

\section{(2) 現在気候での検証}

JRA-55+Wave再解析值を真值と考え, 気候モデルの 現在気候再現実験の精度の確認を行った。まず，JRA-55 とMRI-AGCM3.2Hのモデルの差を検証するために，MRIAGCM3.2Hの現在気候の説明変数 $\left(U_{10}^{2}, S L P, \Delta S L P\right)$ の精度について解析した. その結果， $U_{10}^{2}$ の精度は，全 体で約10\%, 赤道域や陸との境界, 南アメリカ大陸の南 端付近で約 $20 \%$ 誤差を持つことが分かった．大陸近傍 では，海上風の振る舞いが複雑なため，精度が悪い。一

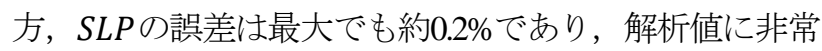
に近い. $\triangle S L P$ は広い範囲で約 $10 \%, S L P$ で比較的精度 の悪い赤道域や陸との境界で約20\%の誤差を示した.

次に, MRI-AGCM3.2Hのタイムスライス実験結果をも とに統計モデルを用いて計算した現在気候の波高の推定 值と, JRA-55+Wave 再解析值の比較を行った. どの統

表-3 月平均波高の海域別の相関係数

\begin{tabular}{c|l|l|l|l|l|l|l|l|l|l|l|l}
\hline & 1月 & 2月 & 3月 & 4月 & 5月 & 6月 & 7月 & 8月 & 9月 & 10月 & 11月 & 12月 \\
\hline 北インド洋 & 0.85 & 0.83 & 0.70 & 0.75 & 0.87 & 0.89 & 0.85 & 0.81 & 0.85 & 0.82 & 0.85 & 0.83 \\
北西太平洋 & 0.87 & 0.84 & 0.83 & 0.85 & 0.86 & 0.85 & 0.84 & 0.88 & 0.86 & 0.86 & 0.86 & 0.83 \\
北東太平洋 & 0.73 & 0.68 & 0.69 & 0.75 & 0.76 & 0.74 & 0.77 & 0.80 & 0.77 & 0.75 & 0.70 & 0.76 \\
北大西洋 & 0.84 & 0.81 & 0.82 & 0.84 & 0.87 & 0.84 & 0.84 & 0.85 & 0.82 & 0.81 & 0.82 & 0.79 \\
南インド洋 & 0.82 & 0.83 & 0.83 & 0.76 & 0.73 & 0.79 & 0.77 & 0.78 & 0.77 & 0.76 & 0.76 & 0.79 \\
南太平洋 & 0.75 & 0.75 & 0.74 & 0.78 & 0.73 & 0.76 & 0.76 & 0.78 & 0.79 & 0.73 & 0.76 & 0.76 \\
南大西洋 & 0.77 & 0.74 & 0.78 & 0.80 & 0.81 & 0.80 & 0.81 & 0.80 & 0.83 & 0.78 & 0.83 & 0.80 \\
赤道域 & 0.63 & 0.59 & 0.51 & 0.53 & 0.58 & 0.65 & 0.71 & 0.64 & 0.68 & 0.64 & 0.56 & 0.61 \\
南極海 & 0.80 & 0.84 & 0.81 & 0.81 & 0.82 & 0.78 & 0.80 & 0.81 & 0.83 & 0.84 & 0.74 & 0.75 \\
\hline 全球 & 0.77 & 0.76 & 0.74 & 0.76 & 0.76 & 0.77 & 0.78 & 0.79 & 0.79 & 0.76 & 0.75 & 0.75 \\
\hline
\end{tabular}


計モデルによる結果も大部分の海域でJRA-55+Wave再 解析との差は-0.1〜 0.2mで $10 \%$ 程度に収まった。陸と の境界では大きな差が生じたが, 説明変数の精度の直接 的な影響が支配的である. また，北大西洋や南アメリカ 大陸南部周辺で $0.3 \sim 0.4 \mathrm{~m}$ の大きな差が生じた. これはこ の海域における波高の值が大きいためであり，誤差は10 〜15\%に収まっている. 一方，南極海や北極海の差は大 きく, 統計モデルでは海水の季節変動を予測の要素に入 れてないことが主要因であると考えられる.

以上より，統計モデルからの推定波高の現在気候での 精度は約10\%であることがわかった。 また，南極海や北 極海, 陸近傍では特に精度が悪い. 北大西洋や南アメリ 力大陸南部周辺，赤道域でも精度が悪いことがわかった。

\section{(3) 将来気候予測}

最後に，統計モデルを全球大気気象モデルの将来気候 予測結果に応用し，波高の将来変化予測を行った．以下 では, 得られた予測結果について, 月平均波高と極大波 高に分けて考察する.

\section{a) 月平均波高}

$U_{10}^{2}$ のみを説明変数とするモデルを用いた場合の，現 在気候の波高に対する平均波高の将来変化量の割合を, シナリオ毎に図-2に示寸．図中の点は，精度検証におい て相関係数が 0.8 を超えた場所を表す.

海域毎の将来変化特性は以下のとおりである.すべて の統計モデルおよび将来シナリオの結果に共通して, 北 太平洋北部で波高の大きな増大, 北大西洋全域と北緯 南緯30付近, および太平洋赤道域の東部で大きな減少 が見られる. 南北太平洋, 南インド洋のそれぞれの中緯 度と, 北西太平洋, 北大西洋, 北インド洋ではシナリオ が高位になるにしたがって波高減少の傾向が増大寸る.

ついで，北太平洋北部では波高上昇の程度が，シナリ オが高位になるにしたがって減っている．また南極海の 将来変化は, RCP2.6では大部分で減少傾向を示している が，RCP4.5になると一部で増加傾向が現れ，RCP6.0, 8.5 と放射強制力が増大寸るとさらに増加する. また，北太 平洋北部，ヨーロッパの西側，オーストラリア大陸東側 では，特に冬季の波高変化が夏季の波高変化より卓越し， 年間平均波高に影響を与えている.

\section{b) 極大波高}

極大波高の将来変化については, $U_{10}^{2}, S L P, \triangle S L P$ の 3つを説明変数とするモデルを用いた場合の現在気候の 波高に対するシナリオ毎の将来変化量を緯度方向に平均 した結果を図-3に示寸．図の(b)〜(d)は，全球の海域を経 度毎に3分割して緯度方向に平均した結果である.

多くの海域で, 月平均波高と同様の変化傾向を示し ている. すべての結果において一貫して, 北太平洋北部 とヨーロッパの西側では増加, 南北太平洋, 北大西洋,

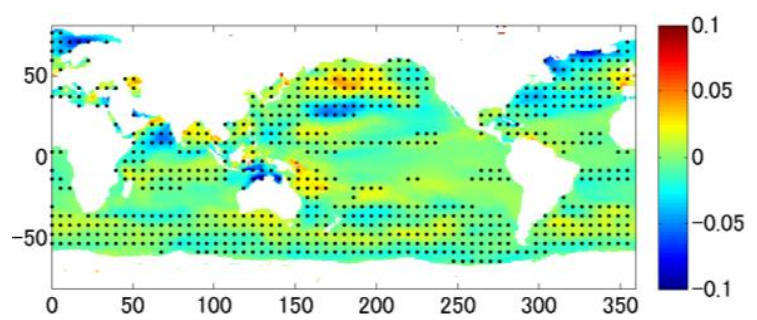

(a) $\mathrm{RCP} 2.6$

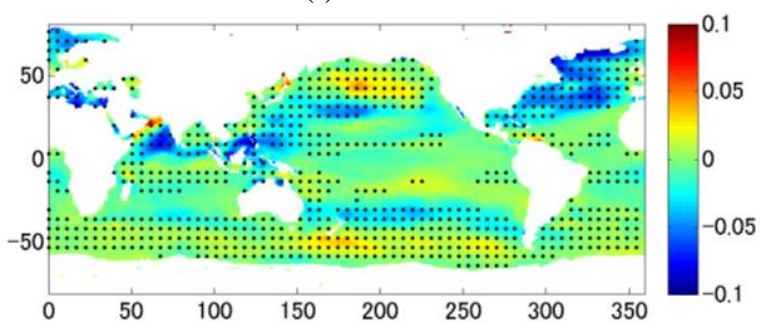

(b) $\mathrm{RCP} 4.5$

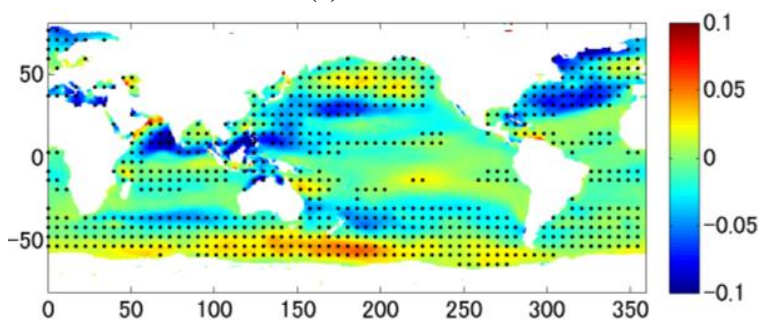

(c) RCP6.0

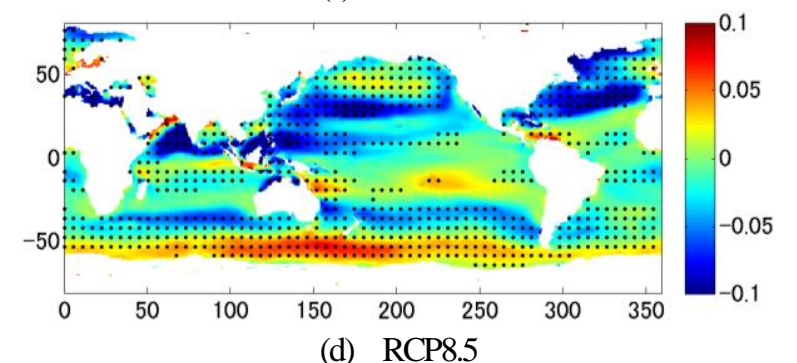

図-2ＭRI-AGCM3.2Hにもとづく平均波高の将来変化率 (説明変数: $U_{10}^{2}$ )

南北インド洋のそれぞれの中央部では減少する．一方， 熱帯低気圧通過領域においては月平均波高とは異なる変 化をしている. 日本近海や南インド洋のマダガスカル島 の東側では，シナリオが高位になるとともに波高は増加 から減少に転じる. 北アメリカ大陸の西側では増加傾向 を示す領域が現れる.オーストラリア大陸の東側では極 大波高が減少寸る領域が月平均波高より広がり， RCP2.6 シナリオでは南北に細く伸びる増加領域が現れる.

\section{6. 結論}

本研究では, 気候モデルによる将来変化予測結果を対 象に，低計算負荷で波高を推定する統計的手法を開発し， 全球の波高推定，精度の検証およびこれを用いた将来変 化予測を行った. JRA-55を基本データとして開発した統

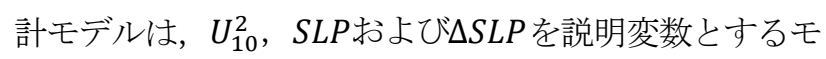
デルであり, 組み合わせを変えて7つの統計モデルを構 築し, 精度検証を行った. 

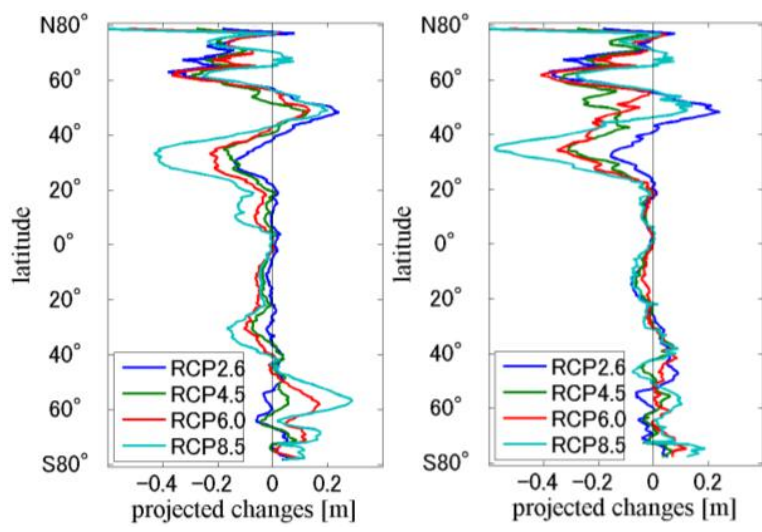

(a) 全球

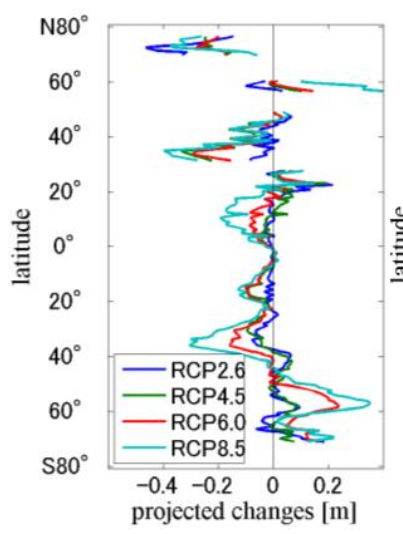

(c) インド洋

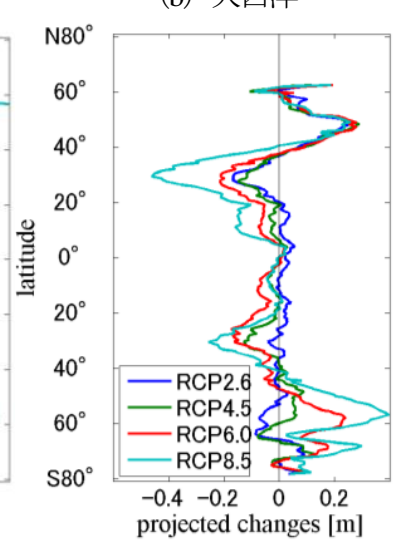

(d) 太平洋

図-3 経度毎に平均した $99 \%$ 極大波高の将来変化 $[\mathrm{m}]$ (説明変数: $U_{10}^{2}, S L P, \nabla S L P$ ) (a) は全球， (b) は西経 $90^{\circ}$ から東経 $20^{\circ}, \quad$ (c) は東経 $20^{\circ}$ から $120^{\circ}$, (d) は東経 $120^{\circ}$ から西経90゚の経度毎の平均值

得られたモデルを, 気象研究所全球大気モデルMRIAGCM3.2Hの気候変動予測実験結果に適用し, RCPシナ リオ毎に今世紀末を対象に波高の将来変化予測を行った. 平均波高の将来変化は，北太平洋北部で波高の大きな増 大, 北大西洋全域と北緯・南緯 $30^{\circ}$ 付近, 太平洋赤道域 の東部で大きな減少が見られた．極大波高は，概初平均 波高と同様の変化の分布を示した．極大波高が平均波高 と異なる特徴を示したのは，主に熱帯低気圧が通過する 海域であり, その変化は温室効果ガスの将来濃度シナリ オがシビアになるにしたがって顕著な変化を示した.

謝辞 : 本研究は, 文部科学省気候変動リスク情報創生プ ログラムおよび科学研究費補助金による成果である.

\section{参考文献}

1) IPCC: Contribution ofWorking Group I to the Fifth Assessment Report of the Intergovernmental Panel on Climate Change, Chapter 13, Cambridge Univ. Press, pp.1139-1216, 2007.

2) Suh, K. D., Kim, S. W., Mori, N., and Mase, H.: Effect of climate change on performance-based design of caisson breakwaters. Journal of Waterway, Port, Coastal, and Ocean Engineering, Vol.138, No.3, pp.215-225, 2011.

3) Chawla, A., Spindler, D. M., and Tolman, H. L.: Validation of a thirty year wave hindcast using the Climate Forecast System Reanalysis winds. Ocean Modelling, Vol.70, pp.189-206, 2013.

4) Hemer, M. A., Katzfey, J., and Trenham, C. E.: Global dynamical projections of surface ocean wave climate for a future high greenhouse gas emission scenario. Ocean Modelling, Vol.70, pp.221-245, 2013.

5) Wang, X. L., \& Swail, V. R.: Climate change signal and uncertainty in projections of ocean wave heights. Climate Dynamics, Vol. 26, No.2-3, pp.109-126, 2006.

6) Wang, X. L., Feng, Y., and Swail, V. R.: Changes in global ocean wave heights as projected using multi-model CMIP5 simulations, Geophysical Research Letters, Vol.41, No.3, pp.1026-1034, 2014.

7) Kobayashi, S., Ota, Y., Harada, Y., Ebita, A., Moriya, M., Onoda, H., Onogi, K., Kamahori, H., Kobayashi, C., Endo, H., Miyaoka, K., and Takahashi, K.: The JRA-55 reanalysis: General specifications and basic characteristics. 気象 集誌. 第 2 輯, No.93, Vol.1, pp.5-48, 2015.

8) Tolman, H. L.: User manual and system documentation of WAVEWATCH III version 4.18. NOAA / NWS / NCEP / MMAB Technical Note 316, 2014.

9) 森 信人, 志村智也, 釜堀弘隆, Arun Chawla, 安田 誠宏, 間瀬 肇: JRA-55 にもとづく長期波浪推算と波 候特性の解析, 土木学会論文集 B2(海岸工学), Vol. 71, 2015.（投稿中）

10) Murakami, H., Mizuta, R., and Shindo, E.: Future changes in tropical cyclone activity projected by multi-physics and multi-SST ensemble experiments using the 60-km-mesh MRI-AGCM, Climate dynamics, Vol. 39, No.9-10, pp.2569-2584, 2014.

(2015.3.18 受付)

\section{STATISTICAL MODELING OF GLOBAL WAVE HEIGHT AND ITS APPLICATION TO CLIMATE CHANGE PROJECTION}

\section{Nobuhito MORI, Risako KISHIMOTO, Tomoya SHIMURA, Tomohiro YASUDA and Hajime MASE}

A statistical model of global wave height analysis was developed based on the JRA-55 reanalysis data and applied to future projections of wave climate change under several future scenarios. Mean and extreme wave heights were estimated globally using the statistical wave model. The estimated mean wave heights in future climates show increase in the Northwestern Pacific and decrease in the Northestern Pacific, middle latitude and around the equator. The estimated extreme wave heights in future climates shows different trends from mean one depending on the future greenhouse gas emission scenarios. 